\title{
PENGARUH PRUDENCE DAN FAMILY OWNERSHIP TERHADAP NILAI PERUSAHAAN DENGAN KEBIJAKAN DIVIDEN SEBAGAI VARIABEL INTERVENING
}

\author{
Zulfa Rosharlianti \\ Universitas Esa Unggul \\ rosharlianti@gmail.com
}

\begin{abstract}
The purpose of this research is to analyze the influence of prudence and family ownership on firm value with dividend policy as an intervening variable in Indonesian family company listed in Indonesia Stock Exchange on period 20112015.

Firm value is measured by Tobin's $Q$, while dividend policy is used as intervening variable is measured by Dividend Payout Ratio (DPR). This research is used 67 samples of family companies listed in Indonesia Stock Exchange for period 2011-2015. The analysis technique used multiple regression and path analysis with SPSS 20.

The results showed: (1) prudence and family ownership simultaneously affects to dividend policy, (2) prudence partially not affects to dividend policy, (3) family ownership partially affects to dividend policy, (4) prudence and family ownership simultaneously affects to firm value, (5) prudence partially affects to firm value, (6) family ownership partially not affects to firm value, (7) dividend policy affects to firm value, (8) dividend policy is an intervening variable.

Research found that dividend policy is an intervening variable between prudence and family ownership simultaneously to firm value to the value of the indirect effects is same than the direct effect $(0,088=0,088)$.
\end{abstract}

Keywords: Prudence, Family Ownership, Firm Value and Dividend Policy.

\begin{abstract}
Abstrak
Penelitian ini bertujuan untuk mengkaji pengaruh prudence dan family ownership terhadap nilai perusahaan dengan kebijakan dividen sebagai variabel intervening di perusahaan keluarga yang terdaftar di Bursa Efek Indonesia periode $2011-2015$.

Variabel nilai perusahaan diukur dengan menggunakan Tobin's Q. Variabel intervening yang digunakan dalam penelitian ini adalah kebijakan dividen yag diukur dengan Dividend Payout Ratio (DPR). Penelitian ini menggunakan sampel 67 perusahaan keluarga yang terdaftar di BEI pada tahun 2011 - 2015. Teknik analisis yang digunakan adalah regresi berganda dan analisis jalur (path analysis) dengan SPSS 20.
\end{abstract}


Hasil penelitian menunjukkan: (1) prudence dan family ownership secara simultan berpengaruh terhadap kebijakan dividen, (2) prudence tidak berpengaruh terhadap kebijakan dividen, (3) family ownership berpengaruh terhadap kebijakan dividen, (4) prudence dan family ownership secara simultan berpengaruh terhadap nilai perusahaan, (5) prudence berpengaruh terhadap nilai perusahaan, (6) family ownership tidak berpengaruh terhadap nilai perusahaan, (7) kebijakan dividen berpengaruh terhadap nilai perusahaan, (8) kebijakan dividen merupakan variabel intervening.

Temuan penelitian menunjukkan bahwa kebijakan dividen adalah variabel intervening antara prudence dan family ownership secara simultan terhadap nilai perusahaan dengan nilai pengaruh tidak langsung sama dengan nilai pengaruh langsung $(0,088=0,088)$.

Kata Kunci: Prudence, Family Ownership, Nilai Perusahaan dan Kebijakan Dividen.

\section{PENDAHULUAN}

Kebijakan dividen merupakan salah satu topik yang banyak diperdebatkan di dalam literatur keuangan dan masih menempati tempat yang terkemuka. Banyak penelitian yang telah memberikan kontribusi pemikiran teoritis dan menyediakan bukti empiris yang berkenaan dengan faktor penentu dari suatu kebijakan dividen suatu perusahaan (Muhammad, 2010; Khoury dan MaladJIAn, 2014). Penetapan kebijakan dividen akan berdampak pada tingkat kepercayaan investor terhadap perusahaan. Investor akan menetapkan untuk berinvestasi pada perusahaan yang menetapkan dividen tinggi karena dianggap memiliki prospek baik dimasa depan.

Oleh karena itu kebijakan dividen merupakan isu yang penting dalam sebuah perusahaan yang penetapannya harus seimbang dan memperhatikan semua pihak yang berkepentingan terhadap perusahaan. JIAng Komain (2013) mengatakan bahwa pembayaran dividen dapat menyebabkan kesalahpahaman dan bahkan konflik di antara mitra karena tidak percaya dan keputusan pasti terhadap kebijakan dividen. Ada banyak alasan mengapa perusahaan harus membayar atau tidak membayar dividen. Misalnya, pembayaran dividen penting bagi investor karena pertama, dividen memberikan kepastian tentang kesejahteraan keuangan perusahaan, kedua, dividen menarik bagi investor yang ingin mengamankan pendapatan saat ini, dan ketiga, dividen membantu menjaga harga pasar dari saham. Perusahaan akan terpengaruh secara positif dengan meningkatnya pembayaran dividen atau membuat pembayaran tambahan yang sama. Selain itu, perusahaan tanpa dividen umumnya dipandang menguntungkan ketika mereka menyatakan dividen baru (Gill, Nahun, dan Rajendra, 2010).

Bagi para pemegang saham atau investor, dividen merupakan tingkat pengembalian investasi mereka berupa kepemilikan saham. Bagi pihak manajemen, dividen merupakan arus kas keluar yang mengurangi kas perusahaan, 
sehingga kesempatan untuk melakukan investasi menjadi berkurang. Bagi kreditor, dividen dapat menjadi sinyal mengenai kecukupan kas perusahaan untuk membayar bunga atau bahkan melunasi pinjaman. Kebijakan dividen yang cenderung membayarkan dividen dalam jumlah relatif besar akan mampu memotivasi investor untuk membeli saham perusahaan, karena perusahaan yang memiliki kemampuan membayar dividen diasumsikan masyarakat sebagai perusahaan yang menguntungkan (I Gede, Sutrisno, dan Achsin, 2011).

Untuk mengetahui pembagian dividen suatu perusahaan haruslah dilihat dari laporan keuangannya. Pembuatan laporan keuangan oleh perusahaan sebagai gambaran kinerja manajemen dalam mengelola sumber daya. Laporan keuangan merupakan produkakhir dari proses atau kegiatan akuntansi perusahaan. Laporan tersebut memberikan informasi yang dapat digunakan oleh pihak internal maupun pihak eksternal untuk mengambil keputusan. Keputusan dari pihak internal misalnya, keputusan untuk mengangkat kembali atau mengganti manajemen. Keputusan dari pihak eksternal misalnya keputusan untuk membeli atau menjual investasi mereka di dalam perusahaan atau keputusan untuk memberikan kredit kepada perusahaan.

Laporan keuangan harus memenuhi tujuan, aturan serta prinsip - prinsip akuntansi yang sesuai dengan standar yang berlaku agar dapat dipertanggungjawabkan isinya serta bermanfaat bagi penggunanya. Dimana tujuan laporan keuangan yaitu memberikan informasi keuangan yang dapat dipercaya mengenai posisi keuangan dan hasil usaha perusahaan pada periode tertentu dan memberikan informasi keuangan yang dapat membantu pihak-pihak yang berkepentingan untuk mengintepretasikan kondisi dan potensi suatu usaha.

Suatu laporan keuangan harus menyajikan informasi mengenai perusahan yang meliputi berbagai elemen-elemen laporan keuangan seperti aset, liabiliti/kewajiban, ekuitas, pendapatan dan beban, serta arus kas. Laporan keuangan juga akan lebih bermanfaat apabila memenuhi karakteristik kualitatif (Accounting Principle Board Statement No.4) yaitu relevan, jelas dan dapat dimengerti, dapat diuji kebenarannya, netral, tepat waktu, dapat diperbandingkan dan lengkap. Dalam menyajikan informasi yang berkualitas, akuntansi juga dihadapkan pada keterbatasan atau biasa disebut dengan constraint yaitu, costbenefit relationship, materiality principle, industry practice dan conservatism.

Dalam upaya untuk menyempurnakan laporan keuangan tersebut lahirlah konsep konservatisme. Konsep ini mengakui biaya dan rugi lebih cepat, mengakui pendapatan dan untung lebih lambat, menilai aktiva dengan nilai yang terendah, dan kewajiban dengan nilai yang tertinggi.

Salah satu prinsip yang dianut dalam proses pelaporan keuangan adalah prinsip konservatisme. Penggunaan prinsip ini didasarkan pada asumsi bahwa perusahaan dihadapkan pada ketidakpastian ekonomi dimasa yang akan datang, sehingga pengukuran dan pengakuan untuk angka-angka tersebut dilakukan dengan hati-hati.

Konservatisme merupakan prinsip akuntansi yang jika diterapkan akan menghasilkan angka-angka laba dan aset cenderung rendah, serta angka-angka biaya dan utang cenderung tinggi. Kecenderungan seperti itu terjadi karena konservatisme menganut prinsip memperlambat pengakuan pendapatan serta 
mempercepat pengakuan biaya. Akibatnya, laba yang dilaporkan cenderung terlalu rendah (understatement). Kecenderungan seperti itu terjadi karena konservatisme menganut prinsip memperlambat pengakuan pendapatan dan mempercepat pengakuan biaya.

Banyak pro kontra yang terjadi ketika kita membicarakan konservatisme. Konservatisme dianggap menjadi suatu prinsip yang justru membuat informasi suatulaporan keuangan menjadi bias karena konservatisme pada dasarnya mengakui rugi lebih cepat dan laba lebih lambat. Hal ini akan membuat suatu laporan keuangan tidak mencerminkan kondisi perusahaan yang sebenarnya. Di sisi lain, konservatisme dianggap perlu untuk digunakan untuk mencegah kecenderungan manajemen dalam menilai aset perusahaan secara overstated agar kinerjanya dinilai baik dan harga saham perusahaan dapat meningkat. Konservatisme juga dianggap bisa menyelesaikan masalah keagenan yang terjadi dalam perusahaan dimana masing-masing agen akan berusaha untuk memenuhi kepentingannya.

Di Indonesia, kepemilikan perusahaan masih didominasi oleh kepemilikan keluarga (Lukviarman, 2004; Arifin, 2007; Achmad, 2008; Siregar, 2008; Saputra, 2010; Hadiprajitno, 2013). Beberapa perusahaan keluarga yang masih exist di Bursa Efek Indonesia antara lain Grup Salim dengan PT Indofood Sukses Makmur Tbk (INDF) nya yang banyak bergerak di bisnis sektor barang konsumsi diperkirakan masih punya prospek bagus. Hal ini terlihat dari Dividend Payout Ratio yang walaupun mengalami penurunan di tahun 2013 sebesar 15,77\% namun dapat naik kembali di tahun 2014 menjadi 80,64\%.

Kelebihan dari perusahaan keluarga adalah pada umumnya perusahaan keluarga memiliki sudut pandang jangka panjang terhadap bisnisnya sehingga dapat menghasilkan return yang lebih baik bagi perusahaan (James, 1999; Ibrahim dan Samad, 2010; Din dan Javid, 2012). Pertimbangan dalam berinvestasi pada perusahaan keluarga cenderung lebih berhati-hati dibandingkan dengan perusahaan non-keluarga. Perusahaan non-keluarga cenderung melakukan pertimbangan jangka pendek dengan melihat fluktuasi harga saham. Berbeda dengan perusahaan keluarga yang mempertimbangkan kelangsungan perusahaan jangka panjang sehingga menghasilkan keputusan investasi yang lebih baik (Shyu, 2011). Keputusan investasi yang lebih baik ini akan mendorong profitabilitas dan nilai perusahaan menjadi semakin tinggi. Selain sudut pandang jangka panjang, perusahaan keluarga juga lebih konservatif dalam pengambilan keputusannya (Gudmundson, 1999; Din dan Javid, 2012). Sifat konservatif ini berkonsentrasi pada kekayaan keluarga yang terdapat pada perusahaan, sehingga akan muncul insentif yang kuat untuk meningkatkan profitabilitas perusahaan (Shyu, 2011).

Kekurangan dari perusahaan keluarga adalah hubungan emosi yang tercipta di dalam lingkungan pengelolaan perusahaan akibat hubungan keluarga (Colli dan Rose, 2008; Shyu, 2011). Berbeda dengan perusahaan non-keluarga yang pada umumnya lebih rasional dan logis dalam hubungan bisnis. Hubungan emosi yang terlalu dalam memungkinkan munculnya permasalahan maupun nepotisme. Kekurangan lain yaitu perusahaan keluarga kurang berinovasi sehingga kurang bertumbuh padahal perusahaan perlu untuk merespon dengan cepat pertumbuhan 
pelanggan yang dinamis (Altindag, Zehir, dan Acar, 2011). Sifat konservatif yang sebelumnya menjadi kelebihan dari perusahaan keluarga juga dapat menjadi kekurangan dari perusahaan keluarga karena perusahaan keluarga menjadi tidak berani untuk mengambil resiko (Gudmundson, 1999). Sifat konservatif ini juga menyebabkan perusahaan keluarga tidak dapat bertumbuh. Kekurangan lain adalah adanya benturan antara kepentingan keluarga dan kepentingan perusahaan yang menyebabkan toleransi kepada orang yang tidak berkompeten dan menutup kemungkinan masuknya orang yang sebenarnya berpotensi (McConaughy et al, 1999).

Selain adanya kekurangan dan kelebihan dari perusahaan keluarga, juga terdapat ketidakkonsistenan hasil penelitian sebelumnya yang meneliti dampak perusahaan keluarga pada profitabilitas dan nilai perusahaan yang menimbulkan pertanyaan mengenai dampak dari perusahaan keluarga. Penelitian sebelumnya yang menemukan mengenai hubungan positif antara family control terhadap profitabilitas dan nilai perusahaan di antaranya adalah penelitian dari Martinez, Stohr, dan Quiroga (2007). Martinez, Stohr, dan Quiroga yang mengambil sampel di Chili membuktikan bahwa perusahaan keluarga umumnya memiliki performa kerja yang lebih baik daripada kinerja perusahaan yang non-family. Hasil penelitian dari Andres (2008); Lee (2006); Yammeesri dan Lodh (2004); Amran dan Ahmad (2010); Chu (2011); Altindag, Zehir, dan Acar (2011); Din dan Javid (2012); Rettab dan Azzam (2011); dan Shyu (2011) juga mendukung hasil penelitian dari Martinez, Stohr, dan Quiroga dimana hasil penelitian membuktikan bahwa kepemilikan keluarga memiliki pengaruh positif pada performa dari perusahaan.

Akan tetapi hasil penelitian dari Thailand oleh Connelly, Limpaphayom, dan Nagarajan (2012) bahkan menemukan bahwa perusahaan keluarga memungkinkan tata kelola perusahaan yang ditujukan untuk keuntungan pribadi sehingga berdampak buruk pada profitabilitas dan nilai perusahaan. Penemuan ini sejalan dengan penemuan dari Leksmono (2010), Abdullah et al (2011); Miller (2007); Villalonga dan Amit (2006); Cucculelli dan Micucci (2008); Rehman dan Shah (2013); Fazlzadeh, Hendi, dan Mahboubi (2011); Onder (2003); dan Lauterbach dan Vaninsky (1999) dimana hasil penelitian menemukan bahwa kepemilikan keluarga berpengaruh negatif terhadap profitabilitas dan nilai perusahaan.

Motivasi penulis dalam melakukan penelitian ini adalah berbagai penelitian terdahulu yang mencari hubungan family ownership dan nilai perusahaan, hasilnya masih beragam. Din dan Javid (2012) menyatakan kepemilikan keluarga atau family ownership memiliki pengaruh positif pada nilai perusahaan. Namun berbeda dengan pendapat penelitian lainnya, Leksmono (2010), Abdullah et al (2011) yang menyatakan kepemilikan keluarga berpengaruh negatif terhadap profitabilitas dan nilai perusahaan. Atas dasar tersebut, penulis menambahkan variabel lain, yaitu prudence dan kebijakan dividen yang kemungkinan dapat meningkatkan pengaruh antar variabel penelitian.

Dari uraian latar belakang di atas dapat dikatakan bahwa kebijakan dividen merupakan variabel intervening atas pengaruh prudence dan family ownership 
terhadap nilai perusahaan, sehingga dapat dirumuskan permasalahan sebagai berikut:

1. Apakah prudence dan family ownership secara simultan berpengaruh terhadap kebijakan dividen?

2. Apakah prudence berpengaruh terhadap kebijakan dividen?

3. Apakah family ownership berpengaruh terhadap kebijakan dividen?

4. Apakah prudence dan family ownership secara simultan berpengaruh terhadap nilai perusahaan?

5. Apakah prudence berpengaruh terhadap nilai perusahaan?

6. Apakah family ownership berpengaruh terhadap nilai perusahaan?

7. Apakah kebijakan dividen berpengaruh terhadap nilai perusahaan?

\section{TINJAUAN TEORITIS}

\subsection{Teori Kepatuhan (Compliance Theory)}

Kepatuhan berasal dari kata patuh yang menurut Kamus Besar Bahasa Indonesia, patuh berarti suka menurut perintah, taat kepada perintah atau aturan dan berdisiplin. Kepatuhan berarti bersifat patuh, ketaatan, tunduk, patuh pada peraturan.

Tuntutan akan kepatuhan terhadap ketepatan waktu dalam penyampaian laporan keuangan tahunan perusahaan public di Indonesia telah diatur dalam Undang-Undang No. 8 Tahun 1995 tentang Pasar Modal, dan selanjutnya diatur dalam Peraturan Bapepam Nomor X.K.6, Lampiran Keputusan Ketua Bapepam (OJK) Nomor: KEP-36/PM/2003 tentang Kewajiban Penyampaian Laporan Keuangan Berkala. Perubahan Bapepam dan LK menjadi Otoritas Jasa Keuangan (OJK) sampai saat ini belum mempengaruhi peraturan yang berlaku sebelumnya, sehingga peraturan yang digunakan masih menggunakan aturan yang dikeluarkan oleh Bapepam dan LK (OJK). Peraturan-peraturan tersebut secara hukum mengisyaratkan adanya kepatuhan setiap perilaku individu maupun organisasi (perusahaan publik) yang terlibat di pasar modal Indonesia untuk menyampaikan laporan keuangan tahunan perusahaan secara tepat waktu kepada Bapepam. Hal tersebut sesuai dengan teori kepatuhan (compliance theory).

Teori kepatuhan telah diteliti dalam ilmu-ilmu social khususnya di bidang psikologi dan sosiologi yang lebih menekankan pada pentingnya proses sosialisasi dalam mempengaruhi perilaku kepatuhan seorang individu.

Menurut Saleh (2003: 4) terdapat dua perspektif dasar mengenai kepatuhan hukum yaitu instrumental dan normative.

"Perspektif instrumental mengasumsikan individu secara utuh didorong oleh kepentingan pribadi dan tanggapan-tanggapan terhadap perubahan insentif, dan penalty yang berhubungan dengan perilaku. Perspektif normative berhubungan dengan apa yang orang anggap sebagai moral dan berlawanan dengan kepentingan pribadi mereka. Seorang individu cenderung mematuhi hukum yang mereka anggap sesuai dan konsisten dengan norma-norma internal mereka."

Sulistyo (2010: 15) menyatakan bahwa: "Komitmen normative melalui moralitas personal (normative commitment through morality) berarti mematuhi 
hukum karena hukum tersebut dianggap sebagai keharusan, sedangkan komitmen normative melalui legitimasi (normative commitment through legitimacy) berarti mematuhi peraturan karena otoritas penyusun hukum tersebut memiliki hak untuk mendikte perilaku."

\subsection{Signalling Theory}

Signaling theory pertama kali oleh Bhattacharya (1979). Adanya asimetri informasi yang didapatkan oleh para pemegang saham dengan manajer. Oleh karena itu manajer sebagai orang dalam yang mempunyai informasi yang lengkap tentang arus kas perusahaan akan memilih untuk menciptakan isyarat yang jelas mengenai masa depan perusahaan apabila mereka mempunyai dorongan yang tepat untuk melakukannya. Kenaikan deviden yang dibayarkan dapat menimbulkan isyarat yang jelas kepada pasar bahwa prospek perusahaan telah mengalami kemajuan. Teori ini menjelaskan bahwa informasi tentang cash dividend yang dibayarkan dianggap investor sebagai sinyal prospek perusahaan di masa mendatang. Teori sinyal mengacu pada gagasan bahwa agen mengirimkan informasi kepada principal untuk menciptakan suatu hubungan yang baik. Manajer memiliki informasi lebih langsung tentang perusahaan daripada investor tetapi mereka selalu enggan untuk memberikan informasi yang transparan kepada pemegang saham. Jadi, kebijakan dividen dapat digunakan untuk tujuan informasi dan juga bertindak sebagai sinyal untuk proyeksi perusahaan di masa depan (Ullah,2012).

\subsection{Hipotesis Penelitian:}

\section{1) Prudence dan Nilai Perusahaan}

Penelitian Penman dan Zhang (2002) dalam Fala (2007) menunjukkan bahwa konsistensi dalam menerapkan akuntansi konservatif dengan tidak melakukan perubahan metode akuntansi akan menunjukkan earnings yang berkualitas. Penelitian oleh Mayangsari dan Wilopo (2002) secara statistik juga menunjukkan bahwa nilai pasarperusahaan akan tercermin pada laporan keuangan perusahaan yang menerapkan prinsip konservatisme. Dengan menggunakan $C$-Score sebagai proksi konservatisme, mereka menemukan bahwa total akrual (discretionary dan non discretionary accrual) berpengaruh positif signifikan pada nilai perusahaan.

Menurut hasil penelitian Tjhen et al. (2012) mekanisme konservatisme akuntansi berpengaruh terhadap nilai perusahaan. Hasil tersebut tidak jauh berbeda dengan penelitanyang telah dilakukan sebelumnya oleh Fala (2007). Konservatisme terbukti menghasilkan laba yang lebih berkualitas dengan meminimalisir tindakan membesarkan laba sehingga mampu meningkatkan nilai perusahaan.

\section{2) Kepemilikan Keluarga (Family Ownership) dan Nilai Perusahaan}

Menurut teori keagenan, struktur kepemilikan perusahaan dapat mempengaruhi masalah keagenan dalam suatu perusahaan. Cucculelli and Micucci (2008) menemukan kepemilikan saham keluarga yang besar mempunyai pengaruh negatif bagi kinerja perusahaan. Hal ini terjadi karena 
keluarga cenderung mengambil manfaat pribadi dari perusahaan dengan semakin banyak nilai saham yang di investasikan maka semakin mudah untuk mengendalikan perusahaan. Ketika timbul suatu resiko yang sangat tinggi yang dialami oleh perusahaan, maka pemilik akan cenderung lebih menyelamatkan uang yang mereka investasikan daripada memperbaiki kinerja perusahaan. Anderson dan Reeb (2004) yang melakukan penelitian di Indonesia menemukan bahwa kepemilikan keluarga berpengaruh negatif terhadap kinerja keuangan perusahaan hal ini disebabkan karena perlindungan hukum terhadap investor dalam struktur kepemilikan sangatlah lemah sehingga timbul masalah agensi yang dapat mengganggu kinerja perusahaan (La Porta et al., 2000; Claessens et al., 2000).

\section{3) Kebijakan Dividen dan Nilai Perusahaan}

Hipotesis ini dibangun berdasarkan pada teori bird in the hand. Bird in the hand theory memandang bahwa dividen tinggi adalah yang terbaik, karena investor lebih suka kepastian tentang pengembalian investasinya serta mengantisipasi risiko ketidakpastian tentang kebangkrutan perusahaan. Kemudian didukung pula oleh teori clientele effect. Pada teori clientele effect disebutkan bahwa terdapat banyak kelompok investor dengan berbagai kepentingan dan memiliki penilaian yang berbeda-beda terhadap kebijakan dividen (Sartono, 2008:290). Bhattaccharya (1979) menyatakan bahwa peningkatan dividen merupakan sebuah sinyal positif tentang pertumbuhan perusahaan di masa yang akan datang, karena meningkatnya dividen diartikan sebagai adanya keuntungan yang akan diperoleh di masa yang akan datang sebagai hasil yang diperoleh dari keputusan investasi yang diambil perusahan dengan NPV positif. Apabila perusahaan meningkatkan pembayaran dividen, mungkin diartikan oleh pemodal sebagai sinyal harapan manajemen tentang akan membaiknya kinerja perusahaan di masa yang akan datang. Keuntungan yang akan diperoleh pemegang saham ini akan menentukan kesejahteraan para pemegang saham yang merupakan tujuan utama perusahaan. Dan pada akhirnya akan meningkatkan niali perusahaan. Kenaikan deviden yang dibayarkan dapat menimbulkan isyarat yang jelas kepada pasar bahwa prospek perusahaan telah mengalami kemajuan.

\section{4) Kebijakan Dividen Memediasi Hubungan Prudence dan Nilai Perusahaan}

(Fala, 2007) Penman dan Zhang (2002) menyatakan bahwa konservatisme akuntansi mencerminkan kebijakan akuntansi yang permanen. Secara empiris penelitian mereka menunjukkan bahwa laba yang berkualitas diperoleh jika manajemen menerapkan akuntansi konservatif secara konsisten tanpa adanya perubahan metode akuntansi atau perubahan estimasi. Prinsip ini mencegah terjadinya tindakan membesar-besarkan laba sehingga laba yang dilaporkan menjadi lebih berkualitas. 


\section{5) Kebijakan Dividen Memediasi Hubungan Family Ownership dan Nilai Perusahaan}

Nilai perusahaan merupakan hal yang penting, karena tingginya nilai perusahaan akan diikuti dengan peningkatan kemakmuran pemegang saham (Nasser dan Firlano, 2006). Maka dari itu, banyak penelitian yang meneliti pengaruh antara kepemilikan keluarga dengan nilai perusahaan. Salah satunya, yaitu oleh Anderson and Reeb (2003) yang menemukan bahwa kepemilikan keluarga dapat memfasilitasi operasi dan menambah nilai dari perusahaan sebagai pemegang saham mayoritas yang didorong untuk mengurangi pengambilahlian dari pihak manajer. Selain itu, terdapat keuntungan lain yang diberikan dari kehadiran anggota keluarga dalam perusahaan keluarga yang dapat mengurangi kerugian yang terjadi, yaitu dapat mengurangi agency problem yang terjadi daripada mengganggu dalam pengambilan keputusan yang efisien.

Jika suatu perusahaan memiliki nilai perusahaan yang besar, maka secara teoritis perusahaan akan mampu membagikan dividen yang makin besar. Membagi dividen yang besar akan menarik para investor untuk berinvestasi karena investor melihat bahwa perusahaan tersebut memiliki laba yang cukup untuk membayar tingkat keuntungan yang diisyaratkannya. Hal tersebut menjadi indikator bahwa masa depan perusahaan cukup menjanjikan. Dan dengan demikian keuntungan yang didapat akan dibagikan kepada para pemegang saham dalam bentuk dividen. Dengan dibagikannya dividen kepada para pemegang saham maka harga saham akan naik dan akan meningkatkan nilai perusahaan. Jadi para investor akan menanamkan investasinya diperusahaan. Karena kemakmuran pemegang saham tercermin dari tingginya dividen yang dibagikan. berikut:

Berdasarkan landasan teori di atas, maka dapat disusun hipotesis sebagai

$\mathrm{H}_{1}$ : Prudence dan Family Ownership secara simultan berpengaruh positif terhadap kebijakan dividen.

$\mathrm{H}_{2}$ : Prudence berpengaruh positif terhadap kebijakan dividen.

$\mathrm{H}_{3}$ : Kepemilikan keluarga (family ownership) berpengaruh positif terhadap kebijakan dividen.

$\mathrm{H}_{4}$ : Prudence dan Family Ownership secara simultan berpengaruh positif terhadap nilai perusahaan.

$\mathrm{H}_{5}$ : Prudence berpengaruh positif terhadap nilai perusahaan.

$\mathrm{H}_{6}$ : Kepemilikan keluarga (family ownership) berpengaruh negatif terhadap nilai perusahaan.

$\mathrm{H}_{7}$ : Kebijakan dividen berpengaruh positif terhadap nilai perusahaan.

\section{METODE PENELITIAN}

\subsection{Populasi dan Sampel}

Populasi yang digunakan oleh peneliti dalam penelitian ini adalah perusahaan yang sudah go public yang termasuk dalam perusahaan keluarga dan 
menerbitkan laporan keuangan dan dipublikasikan di Bursa Efek Indonesia (BEI) periode $2011-2015$.

Metode penarikan sampel yang digunakan yaitu metode purposive sampling dimana pengambilan elemen-elemen yang dimasukkan ke dalam sampel dilakukan dengan sengaja untuk memenuhi kriteria yang digunakan dengan catatan bahwa sampel cukup mewakili populasi (Supranto, 2003) oleh sebab itu purposive sampling dipakai agar benar-benar sesuai persyaratan atau tujuan peneliti, maka sampel digunakan apabila memenuhi kriteria-kriteria sebagai berikut:

1) Perusahaan yang terdaftar pada Bursa Efek Indonesia (BEI).

2) Perusahaan tidak bergerak di sector keuangan ataupun pendanaan seperti bank, asuransi, leasing dan securitas.

3) Perusahaan yang masuk kelompok perusahaan keluarga.

4) Selama periode pengamatan, perusahaan tersebut tidak melakukan akuisisi ataupun merger.

5) Perusahaan yang berturut-turut mengeluarkan annual report dari tahun 20112015.

6) Melakukan pembagian dividen baik itu berupa cash dividend, stock dividend maupun dalam bentuk lain dari tahun $2011-2015$.

7) Laporan keuangan perusahaan dinyatakan dalam bentuk Rupiah.

8) Perusahaan yang menyediakan data keuangan yang berhubungan dengan prudence, family ownership, nilai perusahaan dan kebijakan dividen.

\subsection{Definisi Operasionalisasi dan Pengukuran Variabel}

\subsubsection{Nilai Perusahaan}

Nilai perusahaan adalah sutau proksi yang menggambarkan kemakmuran pemegang saham. Dalam penelitian ini nilai perusahaan diukur dengan menggunakan analisa Tobin's Q.

$$
\text { Tobin's } \mathrm{Q}=
$$

\subsubsection{Prudence}

Prudence dalam penelitian ini akan diproksikan dengan earning/accrual measures yaitu selisih antara net income dan cash flow dari kegiatan operasional dengan menggunakan indikator rasio. Metode ini dikenal dengan model Givoly dan Hayn (2000). Earning/AccrualMeasures dapat dihitung dengan rumus sebagai berikut :

$$
\mathrm{ACit}=\mathrm{NI} \text { it }-\mathrm{CF} \text { it }
$$

\subsubsection{Kepemilikan Keluarga (Family Ownership)}

Perusahaan dikatakan memiliki kepemilikan keluarga apabila pimpinan atau keluarga memiliki lebih dari 20\% hak suara (Anderson and Reeb, 2003; Claessens, 2000; La Porta, 1999). Menurut Harijono (2013), penelusuran kepemilikan keluarga dilakukan dengan melihat nama dewan direksi dan dewan komisaris. Jika nama dewan direksi dan dewan komisaris cenderung sama dalam beberapa tahun dan mempunyai saham dalam kepemilikan perusahaan maka bisa saja perusahaan tersebut termasuk dalam kepemilikan oleh keluarga. 
Jika perusahaan dimiliki institusi lain, maka penelusuran kepemilikan dilakukan dengan analisis kepemilikan piramida dan struktur lintas kepemilikan. Setelah ditelusuri maka dapat diketahui jika saham pengendali perusahaan tersebut adalah individu, maka bisa dikategorikan sebagai kepemilikan keluarga.

Kepemilikan Keluarga $=\longrightarrow \quad 100 \%$

\subsubsection{Kebijakan Dividen}

Dividen yang dimaksud adalah bagian dari laba bersih yang diberikan perusahaan kepada para pemegang saham. Kebijakan dividen dalam penelitian ini diproksikan oleh dividend payout ratio.

$$
\mathrm{DPR}=
$$

\subsection{Analisis Data}

\subsubsection{Uji Normalitas Data}

Uji normalitas data ini dilakukan dengan tujuan menguji apakah variabel dependen dan variabel independen yang terdapat dalam variabel regresi memiliki distribusi normal atau tidak. Dalam penelitian ini untuk menguji normalitas data menggunakan kolmogorov smirnov. Uji kolmogorov smirnov adalah dengan membandingkan distribusi data (yang akan diuji normalitasnya) dengan distribusi normal baku. Distribusi normal baku adalah data yang telah ditransformasikan kedalam bentuk Z-score dan diasumsikan normal.

\subsubsection{Uji Linieritas}

Asumsi yang harus dipenuhi adalah asumsi linieritas. Asumsi ini digunakan untuk mengetahui apakah ada hubungan yang linier antara variabel dependen dengan variabel independen. Uji asumsi linieritas dipenuhi apabila nilai variance inflation factor (VIF) disekitar 1 atau tepatnya nilai toleransi mendekati 1 atau tepat 1 .

\subsubsection{Path Analysis}

Path analysis menggambarkan pola hubungan yang mengungkapkan pengaruh seperangkat variabel terhadap variabel lainnya, baik secara langsung maupun tidak langsung melalui variabel lain sebagai variabel intervening. Sebelum digunakan intepretasi, model tersebut akan diuji lebih dahulu dengan menggunakan regresi yang meliputi, uji normalitas dengan uji $\mathrm{K}-\mathrm{S}$, uji autokorelasi dengan uji durbin Watson, uji multikolinieritas melihat tolerance value dan variance inflation faktor (VIF). Berdasarkan model hipotesis yang diajukan, maka dibuatlah sub struktur yang tujuannya untuk menjelaskan dan mempermudah perhitungan sebagai berikut :

$$
\begin{array}{ll}
\mathrm{Z} 1 & : \alpha^{0}+\beta_{1} \mathrm{X}_{1}+\beta_{2} \mathrm{X}_{2}+\varepsilon^{1} \\
\mathrm{Y} & : \alpha^{0}+\beta_{1} \mathrm{X}_{1}+\beta_{2} \mathrm{X}_{2}+\beta_{3} \mathrm{Z}+\varepsilon^{1}
\end{array}
$$

Keterangan:

$\mathrm{Y}=$ Nilai Perusahaan

$\alpha \quad=$ Konstanta

$\beta \mathrm{n} \quad=$ Koefesien regresi untuk variabel bebas 


$$
\begin{array}{ll}
\mathrm{X}_{1} & =\text { Prudence } \\
\mathrm{X}_{2} & =\text { Family Ownership } \\
\varepsilon & =\text { Error } \\
\mathrm{Z} & =\text { Kebijakan Dividen }
\end{array}
$$

Gambar 1

Koefisien Jalur (Path Analysis)

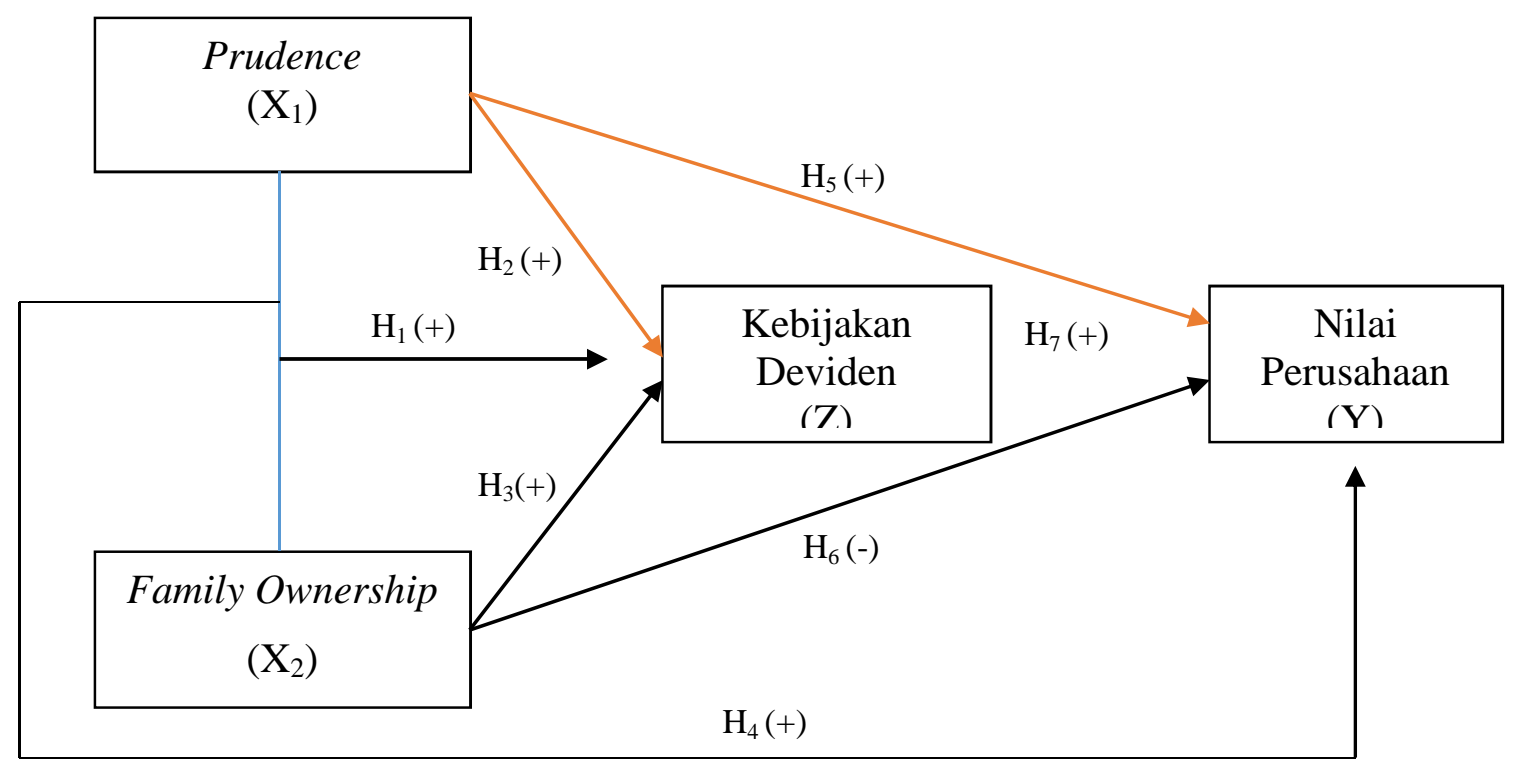

\section{HASIL DAN PEMBAHASAN PENELITIAN}

\subsection{Statistic Deskriptif}

\section{Tabel 1}

Hasil Statistik Deskriptif

Descriptive Statistics

\begin{tabular}{|l|r|r|r|r|r|}
\hline & $\mathrm{N}$ & $\begin{array}{c}\text { Minimu } \\
\mathrm{m}\end{array}$ & $\begin{array}{c}\text { Maximu } \\
\mathrm{m}\end{array}$ & Mean & $\begin{array}{c}\text { Std. } \\
\text { Deviation }\end{array}$ \\
\hline TOBINQ & 335 & -.1784 & 10.3660 & 1.242532 & 1.4160626 \\
PRUDENCE & 335 & -.8007 & .8641 & .128040 & .2211512 \\
FOWN & 335 & 21.61 & 98.55 & 61.1004 & 17.14454 \\
DEV & 335 & -50.97 & 566.67 & 47.0334 & 70.58307 \\
Valid N & 335 & & & & \\
(listwise) & & & & \\
\hline
\end{tabular}

Dari hasil statistik deskriptif dapat dilihat data minimum, maximum, mean dan standar deviasi dari setiap variabel. Berdasarkan hasil statistik deskriptif 
menunjukkan bahwa nilai Tobin's $Q$ memiliki nilai tertinggi $10,36 \%$ dari total 335 sampel yang diamati sedangkan untuk nilai terendah sebesar $-0,17 \%$. Nilai rata-rata dari seluruh sampel yang diamati sebesar $1,24 \%$ dengan nilai standar deviasi sebesar $1,41 \%$. Nilai perusahaan melebihi angka 1 hal ini menunjukkan bahwa nilai pasar saham lebih besar dari nilai bukunya. Semakin besar nilai Tobin's Q menandakan bahwa semakin besar pula harga saham nya.

Berdasarkan hasil statistik deskriptif menunjukkan bahwa Prudence memiliki nilai tertinggi $0,86 \%$ sedangkan untuk nilai terendah sebesar $-0,80 \%$. Nilai rata-rata dari seluruh sampel yang diamati sebesar $0,12 \%$ dengan nilai standar deviasi sebesar $0,22 \%$. Prudence dengan nilai positif yaitu 0,12 menandakan bahwa tingkat prudence perusahaan keluarga di Indonesia masih rendah atau tidak melakukan kehati-hatian (prudence).

Berdasarkan hasil statistic deskriptif menunjukkan bahwa Family Ownership memiliki nilai tertinggi $98,55 \%$ sedangkan untuk nilai terendah sebesar $21,61 \%$. Nilai rata-rata dari seluruh sampel yang diamati sebesar $61,10 \%$ dengan nilai standar deviasi sebesar $17,14 \%$. Itu berarti saham yang beredar secara rata-rata dikuasai oleh keluarga dengan jumlah modalnya 61,10\%, sedangkan sisanya 38,90\% dikuasai oleh diluar dari keluarga baik saham yang dimiliki oleh bank maupun public atau masyarakat.

Berdasarkan hasil statistic deskriptif menunjukkan bahwa Dividen Payout Ratio (DPR) dalam penelitian ini dari seluruh sampel yang diamati memiliki nilai tertinggi 566,67\% sedangkan untuk nilai terendah sebesar $-50,97 \%$. Nilai rata-rata dari seluruh sampel yang diamati sebesar $47,03 \%$ dengan nilai standar deviasi sebesar 70,58\%. Pembagian dividen atas laba tahunan dapat dibilang cukup besar pada perusahaan keluarga yang terdaftar di BEI, hal ini dapat dilihat pada nilai rata-ratanya yaitu $47,03 \%$ yang digunakan untuk membayar dividen dan sisanya $52,97 \%$ digunakan untuk penanaman modal internal.

\subsection{Uji Normalitas}

Tabel 2

Hasil Analisis Uji Normalitas

Runs Test

\begin{tabular}{|l|r|r|r|r|}
\hline & LNTOBQ & LNPRU & LNFOWN & LNDEV \\
\hline Test Value $^{\mathrm{a}}$ & -.17 & -1.80 & 4.09 & 3.35 \\
Cases < Test Value & 161 & 139 & 167 & 165 \\
Cases >= Test Value & 161 & 140 & 168 & 165 \\
Total Cases & 322 & 279 & 335 & 330 \\
Number of Runs & 168 & 133 & 164 & 159 \\
Z & .670 & -.899 & -.492 & -.772 \\
Asymp. Sig. (2-tailed) & .503 & .368 & .623 & .440 \\
\hline
\end{tabular}

a. Median

Pada tabel 4.3 diatas dapat dilihat variabel independen yaitu Prudence memiliki nilai sig sebesar 0,368, Family Ownership memiliki nilai sig sebesar 
0,623 sedangkan variabel dependen yaitu Tobin's Q memiliki nilai sig sebesar 0,503 dan variabel intervening yaitu DPR memiliki nilai sig 0,440 yang berarti untuk model satu setiap variabel memiliki nilai sig diatas 0,05 sehingga data terdistribusi normal.

\subsection{Uji Multikolinearitas}

Asumsi ini digunakan untuk mengetahui apakah ada hubungan linier antara variabel dependen dengan variabel independen. Uji asumsi linieritas dipenuhi apabila nilai tolerance inflation factor (VIF) sekitar 1 atau tepat 1. Dari hasil data olahan SPSS 20 dapat dilihat dalam tabel dibawah ini:

Tabel 3. Hasil Uji Multikolinearitas (Model 1)

\begin{tabular}{|c|c|c|c|c|c|c|c|c|}
\hline \multicolumn{9}{|c|}{ Coefficients $^{\mathrm{a}}$} \\
\hline \multirow{2}{*}{\multicolumn{2}{|c|}{ Model }} & \multicolumn{2}{|c|}{$\begin{array}{c}\text { Unstandardized } \\
\text { Coefficients }\end{array}$} & \multirow{2}{*}{$\begin{array}{c}\text { Standardized } \\
\text { Coefficients } \\
\text { Beta }\end{array}$} & \multirow[t]{2}{*}{$\mathrm{t}$} & \multirow[t]{2}{*}{ Sig. } & \multicolumn{2}{|c|}{$\begin{array}{c}\text { Collinearity } \\
\text { Statistics } \\
\end{array}$} \\
\hline & & $\mathrm{B}$ & Std. Error & & & & Tolerance & VIF \\
\hline \multirow{3}{*}{1} & (Constant) & .210 & .739 & & .285 & .776 & & \\
\hline & LNFOWN & .786 & .176 & .264 & 4.460 & .000 & .980 & 1.021 \\
\hline & LNPRU & .007 & .054 & .008 & .127 & .899 & .980 & 1.021 \\
\hline
\end{tabular}

a. Dependent Variable: LNDEV

Tabel 4. Hasil Uji Multikolinearitas (Model 2)

Coefficients $^{\mathrm{a}}$

\begin{tabular}{|c|c|c|c|c|c|c|c|}
\hline \multirow[t]{2}{*}{ Model } & \multicolumn{2}{|c|}{$\begin{array}{c}\text { Unstandardized } \\
\text { Coefficients }\end{array}$} & $\begin{array}{l}\text { Standardized } \\
\text { Coefficients }\end{array}$ & \multirow[t]{2}{*}{$\mathrm{t}$} & \multirow[t]{2}{*}{ Sig. } & \multicolumn{2}{|c|}{$\begin{array}{c}\text { Collinearity } \\
\text { Statistics }\end{array}$} \\
\hline & B & Std. Error & Beta & & & Tolerance & VIF \\
\hline \multirow{2}{*}{$1 \begin{array}{l}\text { (Constant) } \\
\text { LNDEV }\end{array}$} & -1.360 & .219 & & -6.219 & .000 & & \\
\hline & .338 & .062 & .293 & 5.433 & .000 & 1.000 & 1.000 \\
\hline
\end{tabular}

a. Dependent Variable: LNTOBQ

Berdasarkan tabel diatas dapat diketahui bahwa variabel family ownership perception index memiliki nilai tolerance sebesar 0.980 dan VIF sebesar 1.021. Variabel prudence memiliki nilai tolerance sebesar 0.980 dan VIF sebesar 1.021. Variabel kebijakan dividen memiliki nilai tolerance sebesar 1.000 dan VIF sebesar 1.000. Seluruh nilai yang dihasilkan dalam data olahan menunjukkan bahwa data memenuhi uji asumsi linieritas karena tolerance mendekati 1 dan variance inflation factor nya sekitar 1. Sehingga dapat disimpulkan bahwa model memenuhi uji asumsi linieritas. 


\subsection{Analisis Jalur}

Tabel 5. Hasil Regresi Linier Berganda Uji Langsung Model 1

\begin{tabular}{|c|c|c|c|c|c|c|c|}
\hline \multicolumn{8}{|c|}{ Coefficients } \\
\hline & & \multicolumn{2}{|c|}{$\begin{array}{c}\text { Unstandardized } \\
\text { Coefficients }\end{array}$} & \multirow[t]{2}{*}{ Beta } & \multirow[t]{2}{*}{$\mathrm{t}$} & \multirow[t]{2}{*}{ Sig. } & \multirow[t]{2}{*}{ Kesimpulan } \\
\hline & & B & Std. Error & & & & \\
\hline \multirow{3}{*}{ Equation 1} & (Constant) & .210 & .739 & & .285 & .776 & \\
\hline & LNPRU & .007 & .054 & .008 & .127 & .899 & $\mathrm{H}_{2}$ Ditolak \\
\hline & LNFOWN & .786 & .176 & .264 & 4.460 & .000 & $\mathrm{H}_{3}$ Diterima \\
\hline
\end{tabular}

$Z=0,008 X_{1}+0,264 X_{2}+\varepsilon$

Tabel 6. Hasil Regresi Linier Berganda Uji Tidak Langsung Model 2

\begin{tabular}{|c|c|c|c|c|c|c|c|}
\hline \multicolumn{8}{|c|}{ Coefficients } \\
\hline & & \multicolumn{2}{|c|}{$\begin{array}{c}\text { Unstandardized } \\
\text { Coefficients }\end{array}$} & \multirow[t]{2}{*}{ Beta } & \multirow[t]{2}{*}{$\mathrm{t}$} & \multirow[t]{2}{*}{ Sig. } & \multirow[t]{2}{*}{ Kesimpulan } \\
\hline & & $\mathrm{B}$ & Std. Error & & & & \\
\hline \multirow{4}{*}{ Equation 1} & (Constant) & -.702 & .850 & & -.826 & .409 & \\
\hline & LNPRU & .125 & .062 & .120 & 2.030 & .043 & H5 Diterima \\
\hline & LNFOWN & -.110 & .210 & -.032 & -.526 & .600 & H6 Ditolak \\
\hline & LNDEV & .358 & .067 & .322 & 5.304 & .000 & H7 Diterima \\
\hline
\end{tabular}

\section{Pembahasan Hasil Penelitian}

\section{$\mathrm{H}_{1}$ : Prudence dan family ownership secara simultan berpengaruh positif terhadap kebijakan dividen \\ Berdasarkan hasil penelitian diperoleh bahwa prudence dan family} ownership secara simultan berpengaruh terhadap kebijkan dividen dengan signifikansi sebesar 0,000 . Hasil ini sesuai dengan $\mathrm{H}_{1}$ bahwa prudence dan family ownership secara simultan berpengaruh positif terhadap kebijakan dividen sehingga $\mathrm{H}_{1}$ diterima.

Hal ini menunjukkan bahwa implementasi prudence dan family ownership mempengaruhi kebijakan dividen. Hal ini disebabkan karena prudence secara langsung berpengaruh terhadap laba dan laba ditahan yang digunakan untuk membatasi dividen. Selain itu perusahaan keluarga cenderung lebih sensitif terhadap kekayaan keluarga yang terdapat dalam perusahaan. Oleh karena family ownership sebagian besar kepemilikan sahamnya adalah keluarga, mereka mempunyai daya tawar yang lebih tinggi dibanding perusahaan non keluarga dalam RUPS. Dengan demikian dividend per share akan dipengaruhi oleh kepemilikan dalam suatu perusahaan. 


\section{$\mathrm{H}_{2}$ : Prudence tidak berpengaruh positif terhadap kebijakan dividen}

Dari hasil penelitian diatas menunjukkan bahwa prudence tidak berpengaruh secara positif terhadap kebijakan dividen sehingga $\mathrm{H}_{2}$ ditolak.

Hal ini dapat dilihat dari persentase prudence sebesar $0,12 \%$ yang berarti perusahaan keluarga tidak melaksanakan akuntansi prudence. Sedangkan penerapan prudence dapat mempengaruhi besarnya laba yang dilaporkan. Hal ini menandakan dominasi family ownership lebih tinggi dibandingkan pihak minoritas sehingga kebijakan dividen sebesar 47,03\% lebih tinggi untuk kepentingan family ownership dibandingkan untuk di investasikan kembali.

Hasil penelitian yang sejalan dengan penelitian ini adalah penelitian Shyu (2011) yang menyatakan bahwa penggunaan akuntansi yang semakin prudence akan membuat semakin kecil kemungkinan adanya pembayaran dividen yang terlalu tinggi kepada shareholders.

\section{$\mathrm{H}_{3}$ : Family Ownership berpengaruh negatif terhadap kebijakan dividen}

Variabel Family Ownership diuji secara parsial berpengaruh negatif terhadap Kebijakan Dividen sehingga $\mathrm{H}_{3}$ diterima.

Ini berarti perusahaan yang dikontrol keluarga di Indonesia yaitu sebesar $61,10 \%$ masih memiliki tingkat perlindungan hak pemegang saham yang rendah. Kepemilikan insider yang tinggi akan berdampak pada kecenderungan manajer untuk bertindak demi kepentingannya sendiri, dikarenakan hak voting dan bargaining power yang semakin tinggi yang dimiliki oleh insider dalam penentuan kebijakan sehingga kemungkinan besar pendiri atau keluarga pendiri yang menjadi tim manajemen perusahaan memutuskan untuk menggunakan 47,03\% laba ditahan untuk dibagikan sebagai dividend dan sisanya diinvestasikan kembali. Hal ini disebabkan karena masih besarnya kontrol keluarga berupa kepemilikan saham mayoritas yang dimiliki oleh pendiri atau keluarga pendiri perusahaan.

Hasil penelitian ini sesuai dengan hasil penelitian Wei et Al (2011) dan Sri Rahayu (2010) yang menunjukkan bahwa family ownership berpengaruh terhadap kebijakan dividend dan tidak sesuai dengan hasil penelitian Sugiarto (2008).

\section{H4$_{4}$ : Prudence dan family ownership secara simultan berpengaruh positif terhadap nilai perusahaan}

Berdasarkan hasil penelitian diperoleh bahwa prudence dan family ownership secara simultan berpengaruh positif terhadap nilai perusahaan dengan signifikansi sebesar 0,000 . Hasil ini sesuai dengan $\mathrm{H}_{4}$ bahwa prudence dan family ownership secara simultan berpengaruh positif terhadap nilai perusahaan sehingga $\mathrm{H}_{4}$ diterima.

Hal ini menunjukkan bahwa implementasi prudence dalam perusahaan keluarga akan memberikan nilai tambah di mata investor. Selain itu perusahaan keluarga cenderung berhati-hati dalam mempertimbangkan kelangsungan perusahaan jangka panjang sehingga menghasilkan keputusan investasi yang lebih baik. Keputusan investasi yang lebih baik ini akan mendorong nilai perusahaan menjadi lebih tinggi. 
Hasil penelitian ini sejalan dengan Gudmundson (1999) serta Din dan Javid (2012).

\section{$\mathrm{H}_{5}$ : Prudence berpengaruh positif terhadap nilai perusahaan}

Dari hasil penelitian diatas menunjukkan bahwa prudence berpengaruh secara siginifikan positif terhadap nilai perusahaan sehingga $\mathrm{H}_{5}$ diterima. Ini artinya bahwa, hasil penelitian sudah sejalan dengan teori yang mengatakan bahwa prudence dapat meningkatkan kualitas laba, atau dapat dikatakan bahwa prudence menghasilkan laba yang berkualitas karena prinsip ini mencegah perusahaan melakukan tindakan membesar-besarkan laba dan membantu pengguna laporan keuangan dengan penyaJIAn laba dan aktiva yang tidak overstate (Watts, 2003).

\section{H6: Family Ownership tidak berpengaruh positif terhadap Nilai Perusahaan}

Berdasarkan pengujian yang telah dilakukan, dapat dilihat bahwa Family Ownership tidak berpengaruh positif terhadap nilai perusahaan sehingga $\mathrm{H}_{6}$ ditolak. Hal ini dapat dilihat dari persentase kepemilikan keluarga yang besar yaitu mencapai $61,10 \%$ yang berarti kepemilikan saham mayoritas berada di tangan keluarga. Maka memungkinkan tata kelola perusahaan ditujukan untuk keuntungan pribadi dan mengenyampingkan kepentingan investor sehingga akan berdampak buruk terhadap nilai perusahaan. Selain itu perusahaan keluarga memiliki keunikan serta kelebihan dan kelemahan tersendiri dalam menjalankan usahanya. Sehingga investor tidak terlalu mempertimbangkan apakah suatu perusahaan merupakan perusahaan keluarga atau bukan perusahaan keluarga dalam melakukan keputusan investasinya. Namun lebih melihat pada kinerja kebijakan dividen yang tinggi sehingga harga saham pun meningkat.

Hasil penelitian ini sejalan dengan Leksmono (2010), Connelly, Limpaphayom dan Nagarajan (2012) dimana hasil penelitian menemukan bahwa kepemilikan keluarga tidak berpengaruh terhadap nilai perusahaan.

\section{H$_{7}$ : Kebijakan Dividen berpengaruh positif terhadap Nilai Perusahaan}

Dari hasil pengujian ditemukan bahwa kebijakan dividen berpengaruh positif terhadap nilai perusahaan sehingga $\mathrm{H}_{7}$ diterima. Hal tersebut menunjukkan bahwa apabila kebijakan dividen meningkat maka nilai perusahaan juga akan meningkat.

Hasil penelitian ini sejalan dengan teori Signalling Theory yang diajukan oleh Kusuma (2006:43), motivasi manajemen menyajikan informasi keuangan diharapkan dapat memberikan signal kemakmuran kepada pemilik ataupun pemegang saham. Publikasi laporan keuangan tahunan yang disajikan oleh perusahaan akan dapat memberikan signal pertumbuhan deviden maupun perkembangan harga saham perusahaan. Laporan keuangan yang mencerminkan kinerja baik merupakan signal atau tanda bahwa perusahaan telah beroperasi dengan baik. Signal baik akan direspon dengan baik pula oleh pihak luar, karena respon pasar sangat tergantung pada signal fundamental yang dikeluarkan perusahaan. Investor hanya akan menginvestasikan modalnya jika menilai 
perusahaan mampu memberikan nilai tambah atas modal yang diinvestasikan lebih besar dibandingkan jika menginvestasikan di tempat lain. Untuk itu, perhatian investor diarahkan pada kemampuan perusahaan yang tercermin dari laporan keuangan yang diterbitkan perusahaan.

Hasil penelitian ini juga didukung oleh hasil penelitian Susanti (2010), Perdana (2012), yang menyatakan bahwa kebijakan dividen berpengaruh signifikan dan positif terhadap nilai perusahaan.

\subsection{Kebijakan Dividen Tidak Memediasi Hubungan Prudence dan Nilai Perusahaan}

Dari hasil olahan data SPSS standardized coefficients beta uji tidak langsung prudence perception index adalah sebesar $0.008 \times 0.322$ adalah sebesar 0.0025 nilai ini lebih kecil dibandingkan 0.12 , dengan membandingkan nilai koefisien pengaruh langsung dan tidak langsung menunjukkan bahwa kebijakan dividen bukan merupakan variabel inetervening.

\subsection{Kebijakan Dividen Memediasi Hubungan Family Ownership dan Nilai Perusahaan}

Dari hasil olahan data SPSS standardized coefficients beta uji tidak langsung family ownership perception index adalah sebesar $0.264 \times 0.322$ adalah sebesar 0.085 nilai ini lebih besar dibandingkan -0.032, dengan membandingkan nilai koefisien pengaruh langsung dan tidak langsung menunjukkan bahwa kebijakan dividen adalah merupakan variabel inetervening.

\subsection{Kebijakan Dividen Memediasi Hubungan Prudence dan Family Ownership terhadap Nilai Perusahaan}

Dari hasil olahan data SPSS standardized coefficients beta uji tidak langsung prudence dan family ownership perception index adalah sebesar $(0.008$ x 0.322$)+(0.264 \times 0.322)$ adalah sebesar 0.088 nilai ini sama bila dibandingkan dengan pengaruh secara langsung yaitu $0.12+(-0.032)$ adalah sebesar 0.088 , dengan membandingkan nilai koefisien pengaruh langsung dan tidak langsung menunjukkan bahwa kebijakan dividen adalah merupakan variabel inetervening.

\section{KESIMPULAN DAN SARAN}

\subsection{Kesimpulan}

Berdasarkan hasil pengujian dan pembahasan peneliti dapat meringkas hasil pada penelitian ini sebagai berikut:

1) Prudence dan family ownership secara simultan berpengaruh positif terhadap kebijakan dividen. Karena penerapan prudence berpengaruh terhadap laba dan laba ditahan yang digunakan untuk membatasi dividen. Begitu pula dengan family ownership yang mempunyai daya tawar yang lebih tinggi dibanding perusahaan non keluarga dalam RUPS 
2) Prudence tidak berpengaruh positif terhadap kebijakan dividen. Karena semakin prudence akan membuat semakin kecil kemungkinan adanya pembayaran dividen yang terlalu tinggi kepada shareholders.

3) Family ownership berpengaruh negatif terhadap kebijakan dividen. Hal ini disebabkan karena masih besarnya kontrol keluarga berupa kepemilikan saham mayoritas yang dimiliki oleh pendiri atau keluarga pendiri perusahaan.

4) Prudence dan family ownership secara simultan berpengaruh positif terhadap nilai perusahaan. Karena implementasi prudence dalam perusahaan keluarga cenderung berhati-hati dalam mempertimbangkan kelangsungan perusahaan jangka panjang sehingga menghasilkan keputusan investasi yang lebih baik dan akan mendorong nilai perusahaan menjadi lebih tinggi.

5) Prudence berpengaruh positif terhadap nilai perusahaan. Hal ini dikarenakan perusahaan yang menerapkan prudence menghasilkan laba yang berkualitas sehingga membantu pengguna laporan keuangan dengan penyaJIAn laba dan aktiva yang tidak overstate

6) Family ownership tidak berpengaruh positif terhadap nilai perusahaan. Hal ini disebabkan kepemilikan keluarga yang besar memungkinkan tata kelola perusahaan ditujukan untuk keuntungan pribadi dan mengenyampingkan kepentingan investor sehingga akan berdampak buruk terhadap nilai perusahaan.

7) Kebijakan dividen berpengaruh positif terhadap nilai perusahaan. Karena investor lebih menyukai keuntungan dalam bentuk dividen daripada keuntungan yang diharapkan dari kenaikan nilai modal. Dengan pembagian dividen maka dapat meningkatkan kepercayaan pemegang saham.

8) Informasi akuntansi dalam bentuk prudence dan pembagian dividen merupakan signal goodnews bagi perusahaan untuk meningkatkan nilai perusahaan sehingga market value untuk harga saham ikut naik, maka terjadilah value of the firm.

\subsection{Saran}

Adapun beberapa saran yang dapat dilakukan untuk penelitian mendatang adalah :

1) Perusahaan yang sebagian besar kepemilikan sahamnya adalah keluarga diharapkan dapat tetap menjalankan economic entity dimana setiap perusahaan adalah entitas ekonomi yang independen atau berdiri sendiri yang pencatatannya terpisah dari pemiliknya. Sehingga pemilik saham lain diluar keluarga dapat diperhatikan pula kepentingannya dalam perusahaan tersebut.

2) Untuk para investor sebaiknya lebih cermat dalam melakukan investasi terutama dalam melakukan investasi pada perusahaan dengan struktur kepemilikan yang terkonsentrasi pada keluarga karena dikhawatirkan kinerja perusahaan tersebut lebih buruk dibandingkan dengan perusahaan dengan tipe struktur kepemilikan lainnya. Salah satunya dapat dilihat dari kebijakan dividen nya yang merupakan sinyal bagi corporate action kepada pasar dalam melihat kinerja perusahaan tersebut.

3) Menaikkan issue tentang corporate action diluar dari pembagian dividen, misalnya dengan sharing kepemilikan sehingga persentase kepemilikan 
saham keluarga tidak terlalu besar atau dengan mengambil dewan direksi dari pihak luar sehingga penangambilan keputusan untuk investor diluar keluarga lebih terakomodasi.

4) Adanya konflik antara kepemilikan keluarga dengan kepemilikan manjerial dalam pembagian dividen. Oleh karena itu ada baiknya ditambah variabel kepemilikan manajerial dalam penelitian selanjutnya.

5) Karena family ownership berhubungan dengan principle sedangkan prudence berhubungan dengan agent maka perlu dipertimbangkan untuk penambahan pilar Good Corporate Governance dalam family ownership dan agency theory sebagai landasan teori dalam penelitian selanjutnya.

\section{DAFTAR PUSTAKA}

Anderson, R.C. and Reeb, D. (2003). Founding family ownership, corporate diversification, and firm laverage ", Journal of Law and Economics, Vol. 46 No. 2, pp. 653-84.

Andres, C. (2008). Large shareholders and firm performance - an empirical examination of founding -family ownership", Journal of Corporate Finance, Vol. 14 No. 4, pp. 431-45.

Barth, Erling., Gulbrandsen, Trygve., Pal, Schone. (2005). Family Ownership and Productivity: The Role of Owner-management. Journal of Corporate Finance, Vol.11, 107-127

Bhattacharya, Sudipto.,(1979). Imperfect information, dividend policy, and "the bird in the hand" fallacy, The Bell Journal Economics.

Claessens, S., Djankov, S., Fan, J.P.H., and Lang, L.H.P. (2002). Disentangling the incentive and entrenchment effects of large shareholdings, Journal of Finance, 57(6), 2741-2771.

Financial Accounting Standard Board. (1996/97). Statement o $f$ Financial Accounting Concepts: Accounting Standards. John Wiley \& Sons, Inc.: New York.

Ghozali, I. (2006). Aplikasi Analisis Multivariat dengan Program SPSS. Badan Penerbit.

Ghozali, Imam. (2011). Aplikasi Analisis Multivariate dengan SPSS. Semarang: Universitas Diponegoro.

Gill, Amarjit., dan Biger, Nahum., Dan Tibrewala, Rajendra., 2010, Determinants of Dividend Payout Ratios: Evidence from United States, The Open Business Journal,2010, 3, 8-14

Giovannini, R. (2010). Corporate governance, family ownership and performance". Jour-nal of Management and Governance, 14(2), 145-166.

I Gede, Auditta., Sutrisno., M. Ahcsin.(2011). Pengaruh Agency Cost terhadap Kebijakan Dividen. Pascasarjana Universitas Brawijaya. Terakreditasi SK Dirjen Dikti No. 66b/Dikti/Kep/2011. 
JIAng, Jung., dan Jiranyakul, Komain. (2013). Capital Structure, Cost of Debt and Dividend Payout of Firms. International Journal of Economics and Financial Issues, Vol. 3, No. 1, 2013, pp.113-121

Khoury , Rim El., dan MaladJIAn, Christopher. (2014). Determinants of the Dividend Policy: An Empirical Study on the Lebanese Listed Banks. International Journal of Economics and Finance, Vol. 6, No. 4

Muhammad, Umar Mai. (2010). Dampak Kebijakan Dividen Terhadap Nilai Perusahaan Dalam KaJIAn Perilaku Oportunistik Manajerial Dan Struktur Corporate Governance. Studi Empiris Pada Perusahaan Manufaktur Go Public Di Pasar Modal Indonesia. Disertasi.

Prabowo, M. and Simpson, J. (2011). Independent directors and firm performance in family controlled firms: evidence from Indonesia. Asian Pacific Economic Literature, 25(1), 121-132.

Pukthuanthong, Kuntara., Thomas, J, Walker, \& Dolruedee, Nuttanontra, Thiengtham. (2013). Does family ownership create or destroy value : evidence from Canada. Internasional Journal of Managerial Finance, Vol. 9 No.1, pp. 13-48.

Ratna, Wardhani., dan Ludwina Harahap. (2008). Analisis Komprehensif Pengaruh Family Ownership, Masalah Keagenan, Kebijakan Dividen, Kebijakan Hutang, Corporate Governance Dan Opportunity Growth Terhadap Nilai Perusahaan. Simposium Nasional Akuntansi 17 Lombok.

Shyu, Jonchi. (2011). Family ownership and firm performance: evidence from Taiwanese firms. Internasional Journal of Managerial Finance, Vol. 7 No. 4, 397-441

Silva, F. and Majluf, N. (Agustus 2008). Does family ownership shape performance outcomes?. Simposium Nasional Akuntansi IX. Padang. 23-26

Sugiyono. 2011. Metode Penelitian Kuantatif Kualitatifdan R\&D. Bandung: ALFABETA.

Susanti, Rika. (2010). Analisia Faktor-Faktor yang Berpengaruh Terhadap Nilai Perusahaan (Studi Kasus Pada Perusahaan Go Public yang Listed Tahun 2005-2008). Skripsi Akuntansi Fakultas Ekonomi Universitas Diponegoro.

Villalonga, B. and Amit, R. (2006). How do family ownership control and management affect firm value? Journal of Financial Economics, Vol. 80 No. 2, pp. 385-417.

Wardhani, R. (Agustus 2006). Mekanisme Cor-porate Governance dalam perusahaan yang Mengalami Masalah Keuangan (Financially Distressed firms). Simposium Nasional Akun-tansi IX. Padang. hal. 23-26.

Watts, R. (2002). Conservatism in Accounting. Working Paper, University of Rochester.

Watts, R. (2003). Conservatism in Accounting Part I: Explanation and Implications. Working Paper, University of Rochester.

Watts, R.L., and J.L. Zimmerman. (1986). Positive Accounting Theory. Englewood Cliffs, NJ: Prentice-Hall. 
Yustina, Reny. 2013. "Pengaruh Konvergensi IFRS dan Mekanisme Good Corporate Governance terhadap Tingkat Konservatisme Akuntansi”. Jurnal Ilmiah Mahasiswa FEB, Vol 1, No 2.

Zhang, JIAn, 2011. "The Effect of IFRS Adoption on Accounting ConservatismNew Zealand Perspective”. Thesis, Auckland University of Technology, New Zealand. 